\title{
Consumerisation in UK higher education business schools: higher fees, greater stress and debatable outcomes
}

\author{
Abdul Jabbar ${ }^{1}$ (D) - Bejan Analoui ${ }^{1} \cdot$ Kai Kong $^{1} \cdot$ \\ Mohammed Mirza ${ }^{2}$
}

Published online: 4 October 2017

(C) The Author(s) 2017. This article is an open access publication

\begin{abstract}
For many UK higher education business schools, the continued recruitment of UK, $\mathrm{EU}$ and international students is crucial for financial stability, viability and independence. Due to increasingly competitive funding models across the sector, many institutional leaders and administrators are making decisions typical of highly marketised consumer environments. Thus, this paper explores academics' perceptions of the impact of consumerisation in UK higher education business schools. To achieve this, 22 business school academics were interviewed within three UK higher education institutions (HEIs) in the North of England. Participants had a minimum of three years teaching experience. Data was analysed using template analysis taking an interpretive approach. The findings indicate that academics perceived the introduction of tuition fees to have been the catalyst for students increasing demonstration of customer-like behaviour: viewing the education process as transactional, with the HEI providing a 'paid for' service. It is argued that these changes in UK higher education have created tensions between university leaders and academics, creating genuine dilemmas for those with decision-making responsibilities who must balance academic integrity and long-term institutional financial viability.
\end{abstract}

Abdul Jabbar

a.jabbar@hud.ac.uk

Bejan Analoui

b.analoui@hud.ac.uk

Kai Kong

k.kong@hud.ac.uk

Mohammed Mirza

m.t.mirza@hud.ac.uk

1 Department of Management, University of Huddersfield Business School, University of Huddersfield, Huddersfield, UK

2 Department of Marketing, University of Huddersfield Business School, University of Huddersfield, Huddersfield, UK 
Keywords Leadership - Administration - Tuition fees · Consumerisation · Marketisation ·

Student as consumer

\section{Introduction}

Recently, research has shown there has been an increase in evidence suggesting that consumer-based practices, notions and perceptions are permeating into UK higher education institutions (HEIs) (Nixon et al. 2016; Woodall et al. 2014). Many of these developments have occurred since the introduction of tuition fees, following which UK HEI leaders have implemented strategies, policies and procedures which focus on income and revenue maximisation (Natale and Doran 2012), as opposed to the traditional staple learning and teaching experiences (Marginson 2012; Nixon et al. 2016).

Thus, this paper explores business school academics' perceptions of consumerisation within higher education. The business school academics within the study work within newer universities (post 1992) within the North of England in the UK. Post-1992 universities are 'new' universities which were conferred with a university title by the government in 1992. These new post 1992 institutions are not traditionally orientated towards research output and maintain a focus on the development of student's vocational skills. In order to accomplish this, we define consumerisation as 'a social phenomenon that empowers buyers and consumers, keeping a check on companies to ensure that the customers receive quality products and or services at the correct price'. This definition is based on the work of multiple researchers (Bunce et al. 2016; Lomas 2007; Nixon et al. 2016) who view the student as a consumer and the work of Ritzer (1996), who was one of the first to discuss the 'McUniversity' and its impact on the wider consumer society. The 'McUniversity' refers to the transformation of HEIs from knowledge generators to service providers.

However, Ashwin et al. (2016) disagree with the view of the 'McUniversity' and have suggested that students view higher education as a transformative experience which has positively influenced their worldview and their institutional engagement. The view that students go to university for altruistic reasons is also supported by Budd (2017), who suggests that there is evidence that students reject the consumerist ideology and want to learn, develop and challenge themselves in order to better themselves. While the work of Ashwin et al. (2016) and Budd (2017) have a predominately student perspective, the present work explores academics' perceptions and hence views the phenomenon from a different viewpoint.

The focus on the academic differentiates this work from previous studies which have adopted the student perspective (Ashwin et al. 2016; Budd 2017), the investigation of academic sovereignty within a market orientated environment (Molesworth et al. 2009) and the exploration of leadership within encroaching marketing forces (Lumby and Foskett 2015), allowing the paper to explore what is lesser known, that being the impact of consumeristic ideology upon the academic's role. Though this paper explores academics' perceptions of consumerisation within higher education, it is important to be cognisant of the limitations imposed by the context of the study. 
This study presents the perceptions of business school academics from within three post-1992 institutions and so may not be representative of the UK HE sector as a whole.

\section{Consumerisation in higher education}

While it may seem strange to talk about HE in terms of service and consumers, the introduction of tuition fees by the government to fund undergraduate and postgraduate degrees has created a marketised environment in the UK (Natale and Doran 2012). Originally, government policy set tuition fees to $£ 9000$ per year (Browne 2010) in the hope that not every university would charge this maximum amount, hence creating a market of choice and competition (Coughlan 2010). However, universities not wishing to appear 'second best', or 'second rate', from the offset, charged the maximum amount, thus hardening student attitudes towards education encapsulated in the view 'I've paid my money give me my degree' (Baldwin and James 2000).

In the view of Naidoo et al. (2011), the move towards consumerisation is a global trend with many countries attempting to increase their overall market share of higher education. However, this approach is not universal. For example, although Germany did trial the use of tuition fees, these were quickly abolished due to challenges in the German courts (Kehm 2014). This era of consumerisation has created a twofold problem: firstly, student expectations are increasing (Naidoo and Williams 2015), and secondly, many HEIs have started to make strategic decisions based on market forces which require institutional leaders to consider competitiveness, efficiency and customer satisfaction (Bunce et al. 2016; Naidoo et al. 2011). This has created unintended consequences, with many post-1992 UK HEIs stating that higher education is going through a process of change, with the competition for students increasing, there is pressure to expand both the 'core values' and the branding of the institution, in order to entice students (Molesworth et al. 2009).

This fundamental change has led many HEIs to embrace marketing buzzwords such as differentiation, targeting and competitive advantage. While these strategies and tactics may increase HEI awareness and income, the downside to such an approach has implications for how academics instil pedagogic practices within the materials, modules and programmes they design, and how much control they actually have over these programmes. In the view of some researchers (Marginson and Considine 2002), the drive towards competitive advantage involves creating universal, generic and commodified mass education programmes. These programmes are driven, supported and financed by market forces with the emphasis on cost minimisation, efficiency and student satisfaction through the mechanism of the UK National Student Survey (NSS), which is a high-profile annual census of nearly half a million students across the UK.

The main findings from this paper suggest academic freedom, autonomy, control and support are all but lost or marginalised as HEI courses are developed and marketed centrally, with little or no thought about the student experience (Schapper and Mayson 2004), or, for that matter, the impact on academics. When the focus is on the market model of education, the student as the consumer is 'always right' (De Vita and Case 
2003), which leads to tensions in the student-teacher relationship. As a direct result of this, research (De Vita and Case 2003; Molesworth et al. 2009; Turner 2006) suggests that an increasing number of academics have raised concerns over their increased workload to support students, who lack the skills to be critical learners and who, at times, expect a 24/7 service. In addition to this, Kinman and Jones (2003) mention that academics are expected to publish research alongside the pressure of ever increasing teaching schedules, which has a considerable impact on academic job satisfaction. In what follows, we suggest that the consumeristic conceptualisation of higher education is not inherently problematic. Rather, we propose that it provides a useful frame for exploring and interpreting experience when it is extended to encompass the differences between the provision and consumption of products and services. This argument is underpinned by the recognition that different types of knowledge are involved in the pedagogic experience.

\section{The 'consumption' of higher education}

Marketing texts note that one of the core differences between a product and a service is tangibility (Jobber and Ellis-Chadwick 2012), with some of the defining features of services being that they are less tangible and have an element of co-construction. In this context, Woodall et al. (2014) highlight a number of outcomes from a university education subsumed within practical, social, strategic and personal categories. The physical document is the most tangible outcome and, therefore, the most product like, whereas other outcomes, which may be signified by possession of the degree, including knowledge/learning, transferable skills and business understanding, have greater degrees of intangibility. Thus, the suggestion that the HE system is largely geared towards providing a service is not contentious.

However, there is evidence that some students perceive themselves to be purchasing a product, that is, being in HE to take possession of a degree (Molesworth et al. 2009; Potts 2005) and expecting a good degree in exchange for the fees paid to the university (Naidoo and Jamieson 2005; Potts 2005). As these authors note, students' desire for the degree is instrumental; they wish to use it to secure a job in the labour market. This is a curious notion, as one of the criticisms normally levelled at HE business schools in particular is that they do not always provide an education that equips students for working life (Bennett et al. 1999), and that a business school education often emphasises quantitative skills over softer interpersonal skills (Bennis and O'Toole 2005).

While there are multiple debates, which consider the conceptualisation of knowledge, the tacit/explicit distinction is the most practical and common (Pathirage et al. 2007), with this particular typology having already been applied within a pedagogic context (Analoui et al. 2014). Where students view the purchase of knowledge as a product, they are more than likely holding to a conceptualization of explicit knowledge. Explicit knowledge is understood as being readily transferable between people and places, mostly objective in character, largely context independent and easily expressed in words and formulae (Hislop 2013; Nonaka and Konno 1998). Examples of relevant explicit knowledge within the context of business education may be such 
things as financial formula, definitions of terms and, if veracious, propositional statements such as 'good leaders have good verbal and non-verbal communication', 'performance is a product of ability and motivation' and similar examples.

However, as noted, consideration needs to be given to the softer skills that employers require. Furthermore, the development of these skills is the traditional focus of the institutions in which the present research has been conducted. Such skills are encapsulated within the concept of technical tacit knowledge. This term encompasses the kind of informal personal skills or crafts often referred to as 'know-how' and can be contrasted with cognitive tacit knowledge that consists of beliefs, ideals, values, schemata and mental models, which are deeply ingrained within us (Nonaka and Konno 1998). Relevant examples of technical tacit knowledge in the context of business education include the ability to communicate well using verbal and non-verbal language, mastering practical skills such as using computer software and machinery, and being able to motivate others. Such insights and practical skills are not easily gained, and their acquisition can often be a time-consuming process (Howells 1996; Nonaka and Takeuchi 1995; Polanyi 1966; Ryle 1949). Following Nonaka and Takeuchi (1995), we argue that the gaining of tacit knowledge from another requires the active participation of both individuals in timeconsuming processes (Nonaka and Takeuchi 1995) and so, in the context of HE, requires the active efforts of both educator and student. Given that elements of the process are intangible and involve the co-construction of both parties, it is reasonable to characterise these as service activities.

Hence, we argue that if educators and students recognise the need for the processes that enable the generation of explicit and tacit knowledge, it is then unproblematic for them to perceive themselves respectively as the providers and consumers of services. We suggest that, in return for their fees, educators and the wider HE establishment provide students with the opportunity and support needed to generate different types of knowledge which will be of benefit to themselves and their prospective employers.

\section{Methodology}

To explore business school academics' perceptions of consumerisation, lecturers, senior lecturers and professors who had a minimum of three years' experience of teaching within UK HE business schools were interviewed. This narrow criterion was selected on the merits of its simplicity and to maximise the amount of respondents within the discipline of business (Ritchie et al. 2003).

The research adopted a homogeneous purposeful sampling strategy, from which access was gained to 16 respondents (Ahern 1999; Groenewald 2004; King and Horrocks 2010). The purposeful approach was supplemented with a snowball sampling strategy; an additional six academics were interviewed through this method to bring the total to 22 interviews (9 male academics and 13 female academics), across three different business schools in the North of England. These universities are vocational in nature and, while not traditionally research orientated, are members of the university alliance; hence, for the purposes of this paper, we make the distinction that these universities have the development of students' technical tacit knowledge as a core part of their mission. Table 1 
Table 1 Description of the participants

\begin{tabular}{llr}
\hline Name & Role & Experience (years) \\
\hline Sam & Senior lecturer & 30 \\
Sarah & Senior lecturer & 6 \\
Jim & Senior lecturer & 8 \\
Ayub & Director of education & 12 \\
Chung & Senior lecturer & 20 \\
Paulina & Lecturer & 4 \\
Claire & Senior lecturer & 7 \\
Rebecca & Lecturer & 8 \\
Angela & Lecturer & 4 \\
Liz & Senior lecturer & 7 \\
Lisa & Course leader & 15 \\
Julie & Course leader & 7 \\
Georgina & Senior lecturer & 6 \\
Abtin & Director of education & 25 \\
Chui & Lecturer & 3 \\
Michael & Principal lecturer & 7 \\
Bo & Lecturer & 3 \\
Rodney & Principal lecturer & 30 \\
John & Principal lecturer & 35 \\
Amber & Senior lecturer & 4 \\
Andrew & Lecturer & 27 \\
Emma & Course leader & 9 \\
\hline
\end{tabular}

describes the sample in more detail; the names of the respondents have been changed to protect anonymity.

\section{Data collection}

In order to collect the data, in-depth interviews were conducted with participants, which typically lasted between 50 and $90 \mathrm{~min}$. All interviews were recorded using a smartphone as opposed to a traditional Dictaphone; this allowed for high-quality audio recording as well as instant backup of data to the Cloud (Beddall-Hill et al. 2011); Table 2 highlights the questions asked. In addition to the in-depth interviews, the researchers employed the

Table 2 Interview questions

Interview questions

Question 1: In your own experience, can you describe some of your experiences about what you feel is changing in Higher education?

Question 2: How have these changes impacted on your workload and on the way, you teach?

Question 3: If there have been changes, how do you feel this has influenced you in making you the academic you are?

Question 4: Can you tell me a little bit about student expectations?

Question 5: Has tuition fees changed the way students behave or interact with you?

Question 6: How have tuition fees impacted on you as an academic and on your workload?

Question 7: How do you feel this institution supports you?

Question 8: Has the focus of your institution changed over the last 10-15 years? 
tool of memoing (Miles and Huberman 1994, p. 69), which allows for the collection of non-standard data such as gestures, facial expressions and other non-verbal forms of expression (Creswell 2012; Groenewald 2004). In total, this research involved in excess of $45 \mathrm{~h}$ of collection and transcription of audio recordings, alongside 22 memoing documents.

\section{Data analysis}

Collected audio data was transcribed and organised through the use of template analysis (Brooks et al. 2015; King 2004, 2012) and is outlined in Table 3. This is a relatively new approach and while it may not be as well-known as other qualitative analytical methods such as interpretive phenomenological analysis (IPA), it is regarded in qualitative circles as providing similar analytical rigour and findings (Langdridge 2007). Template analysis refers to multiple but related techniques for thematically organising and analysing codes, and can be applied across multiple methodological and epistemological approaches (King 2004, 2012).

After transcription, the next stage of the analytical process was to implement a coding structure; to achieve this, an a priori code template was generated through a review of the literature, using the ideas and concepts of HE marketisation (Molesworth et al. 2009), students as customers (Lomas 2007) and stressors and strains in UK academics (Kinman and Jones 2003). The a priori code set was used to inform the initial template A (process demonstrated in Table 3). The a priori template is a crucial aspect of the template analysis approach, with King (2004) encouraging the researcher to conceptualise the form of the template and identify how extensive this should be early on. This is supported by other researchers (Crabtree and DiCicco-Bloom 2006; King 2012; Langdridge 2007) who discuss the use of pre-defined a priori codes in helping to structure and analyse the collected interview data.

At this stage, the researchers cross referenced the data with each other, and through the use of a parallel coding, created template B (King 2012). The utilisation of parallel coding (axial coding) allows for segments of text to be classified in two or more different codes at the same level, therefore allowing for the emergence of relationships across clusters and themes (Crabtree and Miller 1999; King 2004). For further validity and consistency between researchers, the data was reviewed for a third time, notes were compared, parallel coding was undertaken and template $\mathrm{C}$ was developed.

In Table 3, the italicised texts highlight new codes that were added to the templates during the creation of template B.

Table 3 Coding templates

\begin{tabular}{|c|c|c|c|}
\hline Priori template & Template A & Template B & Template C \\
\hline $\begin{array}{l}\text { HE marketisation } \\
\text { (Molesworth et al. 2009), }\end{array}$ & Student numbers & $\begin{array}{l}\text { Student numbers } \\
\text { Financial pressures }\end{array}$ & $\begin{array}{l}\text { Student numbers* } \\
\text { Financial pressures* } \\
\text { Admission criteria } *\end{array}$ \\
\hline Students as customers (Lomas 2007) & Value of degree & $\begin{array}{l}\text { Value of degree } \\
N S S\end{array}$ & $\begin{array}{l}\text { Value of degree* } \\
\text { NSS* } \\
\text { Student expectations }\end{array}$ \\
\hline $\begin{array}{l}\text { Stressors and strains in UK academics } \\
\quad(\text { Kinman and Jones 2003) }\end{array}$ & Staff workload & $\begin{array}{l}\text { Staff workload } \\
\text { Staff morale }\end{array}$ & $\begin{array}{l}\text { Staff workload* } \\
\text { Staff morale* } \\
\text { Research and teaching tension* }\end{array}$ \\
\hline
\end{tabular}


Template A builds on the a priori template and highlights the key template codes. These codes are the following: critical issues, the increase in 'student numbers', continuous expectation for 'value of degree' and the issues with 'staff workloads'. This early template shows that the literature gathered as part of the priori template echoes academic perceptions collected within the data.

This is further highlighted in template B which identifies additional depth and context through the cross referencing of data between the researchers. This additional step validates the codes in template A, but also identifies an additional three higher level codes: 'financial pressures', 'NSS' and the phenomena of 'staff morale'. The additional codes give continued understanding of the issues academics face in a rapidly changing cultural and competitive environment, and its impact on pedagogy development.

In template $\mathrm{C}$, the researchers identified additional context for the higher level code 'NSS'; academics now discuss the key issues which they feel damaging their NSS scores, in this case unrealistic 'student expectations'. This template also highlights the pressure between research and teaching; academics are of the view that teaching does not get the same recognition as research. Finally, academics feel that due to financial pressures, academics and institutions drop entry criteria to generate income, creating tensions in the 'admission criteria'. Template $\mathrm{C}$ is an output of the previous three steps and highlights the eight main higher level codes, which are indicated with an asterisk (*). These eight higher level codes are crucial in helping to identify the key three themes that emerge out of the collected interviews as illustrated in Fig. 1.

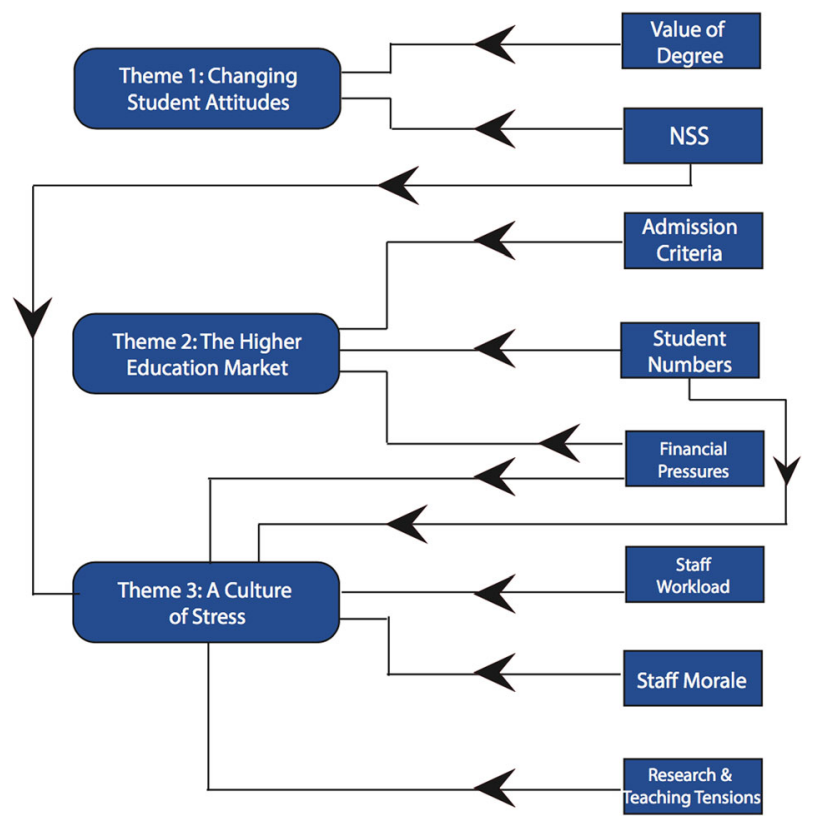

Fig. 1 Key themes to emerge from the data analysis 


\section{Key findings}

\section{Theme 1: changing student attitudes}

The first theme explores the academic perception that students are displaying consumeristiclike behaviour which influences their expectations and perceptions of UK HE. Two academic participants, Rodney and Abtin, state that there has been a fundamental shift in their view, of how student behaviour in and out of the classroom has created behavioural and pedagogical issues:

University students are becoming like traditional customers they are going to want value for money and they are going to complain (Rodney)

It's treating students as a customer, value for money. They are not coming to the lectures and they want lecture notes to be on Blackboard to make the decision whether to come or not (Abtin)

Both Rodney and Abtin have over 20 years of teaching in UK HE and during this time, they have seen a lot of change; in their view, one of the biggest changes is students now paying for their tuition. Biggs (2011) agrees that there has been a change and argues that the implementation of fees has prompted many students to reconsider the value of their degree, with many surmising that the degree has now become a transaction. The perceptions of Rodney and Abtin shine a spotlight on traditional marketing concepts, and they were not alone in their views:

I see students more predominantly with non-white ethnic backgrounds who have the attitude, I have paid for this, where is my degree? (Emma)

It seems strange to talk about higher education in terms of service and consumers, even anecdotally when speaking to students there is a massive change in focus; I've paid my money give me my degree (Lisa)

Lisa and Emma were the first to discuss openly the provision of education as a product, and hence there, they propose that for students, there is a sense of 'transactional entitlement', the fees have been paid, deliver my degree. In the view of John, this sense of entitlement creates an expectation that a poor-degree classification equates to a poor product purchase:

I think a good number of students feel if they end up with a mediocre degree they have not received fair value. They think that they've been sold or they bought a poor product. (John)

Increasing customer expectations is not a new phenomenon and has been studied extensively in marketing circles, where the notion of a poor product is steeped in poor customer experience literature (Carù and Cova 2003). However, this is arguably relatively new in UK HE with 45\% of the academics interviewed feeling that $\mathrm{HE}$ was at a tipping point, and there was a prioritisation towards the rights of the consumer over the acquisition, retention and utilisation of knowledge, and surprisingly, the students have a nonchalant attitude towards learning: 
I say to them if you are interested in knowledge stay. I also ask why are you here? And I

find that the ambition and aspiration, it's not there. (Abtin)

It seems that here Abtin is discussing a general point where students are disengaged from the teaching and learning process; this is not necessarily the fault of the student or an output of consumerisation but in the view of Hardy and Tolhurst (2014) a wider problem where academics are struggling to engage students in UK HE pedagogy.

In closing this theme, the general feeling from the respondents is one of trepidation in an environment where, as much of the literature notes (Beaty et al. 1997; Olssen and Peters 2005), the role of universities as purveyors of knowledge has been significantly weakened.

\section{Theme 2: the higher education market}

This concept of the market is ideologically based on the principles of capitalism, and in the opinion of Marginson (2002) a mechanism to create choice and competition in the HE sector. A significant majority of those interviewed had strong views on the HE market and there was a strong recognition that while there are positive elements, the negative side effects were weighing heavily on academic time, workloads and well-being. Many of these adverse effects originate from competing internally and externally for the 'best' students, particularly international students, on whom so much rests financially (Baldwin and James 2000; De Vita and Case 2003; Jabbar and Hardaker 2013).

I think the university tries to recruit more international students and faster. (Bo)

When the bottom line is if the institution doesn't make enough money and isn't viable then it's not going to exist (Lisa)

The incentive to recruit international students' income creates a highly pressurised environment, where the mantra 'survival of the fittest' is now prevalent. This pressure can create scenarios where there may be considerable conflicts of interest for institutions and academics. One such area is the admission of students; in this research, we found evidence to suggest that students, who may not have been eligible in the past, are now offered a place due to their financial ability to pay, as opposed to their academic ability. While moral judgement may be passed on this by some, Chui suggests that this is a necessary to protect jobs and institutional viability:

At this university sometimes we can't meet our standards, so I think we sacrifice the quality of the students to get more students to come, that's why we have very poor quality students (Chui)

I think a university, like any organization, has to change approach and become streamlined and efficient in its provision (Julie)

While Chui provides a very controversial perspective, it is important to recognise that this was a minority view. However, the drive towards efficiency, value and revenue does perhaps suggest that the HE market does have its challenges. What Chui and to an extent Julie are alluding to is the disparity between commercial interests and scholarly activities, fuelled by the 
free market concept that spiralling HE costs need private investment. For Lynch (2006), this is a convenient ploy by neo-liberal governments to extricate themselves from funding HE.

\section{Theme 3: a culture of stress}

The final theme of this research reports academic experiences of increased pressure and stress due to the competitive nature of the HE environment. Participants attributed this culture of stress towards the institutions' perception of students as fee-paying consumers. This view was held by the majority of respondents during the interview process, and interestingly, the majority of the higher-level codes (63\%) relate to or are deemed to contribute to a culture of academic stress where HE academic staff feel underpaid, pressured, demoralised and demotivated:

This has been a really tough year for me because I think it's been a really tough year for the school within our department we have been really under staffed I've been kind of thrown in at the deep end. (Angela)

We've got so many pressures now from university. We are required as staff to do a hell of a lot more things of which teaching now is just one element. (Ayub)

Both Angela and Ayub are very vocal about the extra demands that have been placed on them in the last few years. Ayub refers to teaching as just one element of his workload, his concerns also relate to increased demands, which include conducting research and carrying out administrative duties. The additional workloads can impact on academic well-being in a negative manner with Kinman and Jones (2003) detailing the consequences of work-related stress contributing to high levels of divorce in some UK institutions.

The unmanageable workloads and time pressures which may lead to deteriorating levels of performance also significantly contribute to the diminishing amount of time academics spend with their students:

We can't lose sight of the teaching and sometimes it feels like there is so much to do in so little time. For e.g. if you don't get ninety percent in your NSS which is all about teaching at the end of the day then you are on the naughty step. (Rebecca)

This time, I suppose, really, has been the year where I've had the biggest group of international students in a module. Too many students, not enough time. (Sarah)

Sarah and Rebecca appeared to display a certain amount of guilt and frustration that their students were being neglected, providing a poor student experience due to the extreme stress they reported experiencing. However, not every academic felt the same way:

To be blunt, I've been absolutely determined to resist the pressure. The reason for doing so is that I have limited time with regards to employment here, I intend to fully retire in the near future and therefore I don't intend to spend a lot of time getting stressed. (John)

John will soon retire and so his focus is on supporting those students who need help in a way in which he feels comfortable.

However, $77 \%$ of the respondents in this research have less than ten years' experience of teaching in UK higher education, so this option may not be open to them. The majority of 
these 'young' academics feel undervalued and increasingly forced to make a choice between teaching and research:

Research \& teaching they have tension, they are in conflict with each other, because when you have teaching you have to sacrifice your time on research, so that's why a lot of people, they don't spend a lot of time on the teaching side because teaching is not rewarded. (Chui)

The net output of these extra demands is the notion that academic professional autonomy is decreasing, with many respondents of the view that academia can now be deconstructed into simple layman terms such as products and services, resulting in the perception that academics are 'call handlers', as alluded to by Amber:

Students can do everything else instantaneously, so why not contact me instantaneously, they can do all their banking online, every organization virtually they deal with operates on a 24 hour, so why the hell doesn't the University? (Amber)

This perceived movement towards being labelled as 'call handlers' may well contribute to the disintegration of academics' affection towards their profession and an increase in casualisation (Alvesson and Spicer 2016).

\section{Discussion}

The present study was undertaken to explore business school academics' perceptions of the impact of consumerisation on higher education within three vocational universities in the North of England. The findings of the study demonstrate a range of concerns with respect to lowered student engagement, falling academic standards and increasing pressure and stress amongst academic staff. It is clear that the current model of consumerisation focuses on financial stability and success, which is ill at ease with the traditional view and purpose of HEIs (Meek 2000; Warwick 2014). Consistent with these views, our findings provide insights into extant academics' perceptions of the impact of the consumerist shift on a range of HEI stakeholders.

Consistent with reports from other studies (Naidoo and Jamieson 2005; Nixon et al. 2016), the majority of academics within our study note that student attitudes have changed, with academics perceiving their students to simply expect or want a degree in exchange for their fees. This reported perception is consistent with the notion of purchasing a degree as a product, as opposed to being engaged as the co-creators of a knowledge generation service. We contend that this is problematic, as tacit knowledge cannot be simply transferred from one individual to another but requires the active participation of both individuals (Nonaka and Takeuchi 1995). Thus, if students wish to gain the tacit knowledge that underpins soft skills and practical insights during their degree programmes, then they will need to be actively involved in the knowledge generation process.

Precisely what may be done about this is unclear. Respondents in our sample did not simply apportion blame to their students for their attitudes - and we do not wish to do so either, believing it unfair to leave the onus for change with students. We suggest that educators should recognise that regardless of how the consumeristic perception encapsulated in the statement 'I've paid for my degree' was generated, it needs not be maintained. While a full examination of how such attitudes might be altered is beyond the scope of this work, we propose that educators do not to argue against the notion that students are consumers but rather to emphasise that what is being 'consumed' is a co-created service, and not a product. We expect 
that if successful, the resulting change in attitude will encourage a more active engagement amongst those students who were previously passive. In making this proposal, we also advise caution, being cognisant of Long and Lake's (1996, p. 111) argument that

"An overzealous application of the service metaphor to teaching inverts the relationship by vesting authority in students as consumers" and that such consumerism contributes to the deleterious notion that students are "... to be served only in ways they find pleasing".

Another change that participants attributed to the marketisation of HE concerned the manner in which they were being required to recruit students to their programmes. Some participants highlighted increased pressure to compete both internally within their own institutions and externally for the best possible students. While in tandem, also being encouraged to recruit larger numbers of students to help maintain the financial viability of their programmes or institutions. Although in the minority, some participants also highlighted that students were being accepted onto courses who had lower qualifications than would previously have been acceptable, raising concerns over the quality of provision.

Thus, there are evident differences between the approaches adopted within HEIs with some academics being encouraged to recruit the best students, some being encouraged to accept students with less than desirable qualifications and the majority of academics being encouraged to recruit as many students as possible. As with other studies (Alvesson and Spicer 2016; Kinman 2001; Tytherleigh et al. 2005), it was argued that that these approaches to managing and running HEIs had been a precursor for increased levels of stress and workloads, which focus on reducing costs and increasing efficiency to the detriment of teaching excellence (Natale and Doran 2012; Schapper and Mayson 2004). Indeed, academics within our sample reported that they now deliver more teaching hours and feel they have less time to deliver quality teaching, while simultaneously being expected to provide an on-demand service for their students. Despite this trend towards greater volumes of teaching, it was reported that paradoxically, academic leaders and their institutions are increasingly placing greater value on research output. Thus, we argue that in general, academics within our sample perceive the changes to their environment to have been detrimental, being particularly difficult and demoralising for those whose focus is on and value their role as educators.

\section{Limitations and future research}

As is the case with most qualitative studies, there are limitations which suggest directions for future research (Margolis and Molinsky 2008). As part of this research, we collected the years of service of each respondent and attempted to develop a balanced sample across academic experiences, roles and institutions. In taking this forward, there is the potential to investigate additional nuanced variables. For example, there is a scope to investigate perceptions based on academic seniority, making distinctions between lecturers, senior lecturers, professors and academic managers. This approach could be investigated in conjunction with classroom contact hours investigating how position and contact can impact on student engagement and integration. Other future areas of research could investigate the perceptions of academics from a variety of disciplines and institutional types. Furthermore, the perspectives of other stakeholders could also be sought, including students and academic managers to provide a more nuanced perspective. Such insights may provide additional understanding of consumerisation. 


\section{Conclusions}

Academics within our sample attribute a number of negative outcomes to the consumerization of higher education within their institutions. These include an increase in transactional attitudes amongst students that are not conducive to learning, pressures to recruit a greater volume of students, increased workloads and additional stress, and concerns over the quality of provision. We concede that university leaders cannot ignore business considerations and financial costs in running a college or university (Naidoo et al. 2011; Potts 2005). Yet, we also suggest that those who run HEIs should be cognisant of protecting the quality of their provision and the wellbeing of their staff, while also ensuring that they remain financially viable.

Open Access This article is distributed under the terms of the Creative Commons Attribution 4.0 International License (http://creativecommons.org/licenses/by/4.0/), which permits unrestricted use, distribution, and reproduction in any medium, provided you give appropriate credit to the original author(s) and the source, provide a link to the Creative Commons license, and indicate if changes were made.

\section{References}

Ahern, K. J. (1999). Ten tips for reflexive bracketing. Qualitative Health Research. https://oi.org/10.1177 /104973239900900309.

Alvesson, M., \& Spicer, A. (2016). (Un)Conditional surrender? Why do professionals willingly comply with managerialism. Journal of Organizational Change, 29(1), 29-45. https://doi.org/10.1108/JOCM-11-2015-0221.

Analoui, B. D., Sambrook, S., \& Doloriert, C. H. (2014). Engaging students in group work to maximise tacit knowledge sharing and use. The International Journal of Management Education, 12(1), 35-43.

Ashwin, P., Abbas, A., \& McLean, M. (2016). Conceptualising transformative undergraduate experiences: a phenomenographic exploration of students' personal projects. British Educational Research Journal, 42(6), 962-977.

Baldwin, G., \& James, R. (2000). The market in Australian higher education and the concept of student as informed consumer. Journal of Higher Education Policy and Management, 22(2), 139-148. https://doi. org/10.1080/713678146.

Beaty, L., Gibbs, G., \& Morgan, A. (1997). Learning orientations and study contracts. The Experience of Learning, 2, 72-88.

Beddall-Hill, N., Jabbar, A., \& Shehri, S. (2011). Social mobile devices as tools for qualitative research in education: iPhones and iPads in ethnography, interviewing, and design-based research. Journal of the Research Center for Educational Technology, 7(1), 67-89 Retrieved from http://eprints.hud.ac.uk/10507/.

Bennett, N., Dunne, E., \& Carré, C. (1999). Patterns of core and generic skill provision in higher education. Higher Education, 37(1), 71-93.

Bennis, W. G., \& O’Toole, J. (2005). How business schools lost their way. Harvard Business Review, 83(5), 96-104.

Biggs, J. B. (2011). Teaching for quality learning at university: what the student does (3rd ed.). Maidenhead: BOOK, McGraw-Hill Education (UK).

Brooks, J., McCluskey, S., Turley, E., \& King, N. (2015). The utility of template analysis in qualitative psychology research. Qualitative Research in Psychology, 12(2), 202-222. https://doi.org/10.1080 /14780887.2014.955224.

Browne, L. (2010). Securing a sustainable future for higher education: An independent review of higher education funding \& student finance. Department for Business, Innovation \& Skills. United Kingdom. Retrieved from https://www.gov.uk/government/publications/thebrowne- report-higher-education-fundingand-student-finance.

Budd, R. (2017). Undergraduate orientations towards higher education in Germany and England: problematizing the notion of 'student as customer'. Higher Education, 73(1), 23-37. https://doi.org/10.1007/s10734-015-9977-4.

Bunce, L., Baird, A., \& Jones, S. E. (2016). The student-as-consumer approach in higher education and its effects on academic performance. Studies in Higher Education, 5079, 1-21.

Carù, A., \& Cova, B. (2003). Revisiting consumption experience a more humble but complete view of the concept. Marketing Theory, 3(2), 267-286.

Coughlan, S. (2010). Students face tuition fees rising to $£ 9,000$. Retrieved December 9, 2016, from http://www. bbc.co.uk/news/education-11677862. 
Crabtree, B. F., \& DiCicco-Bloom, B. (2006). The qualitative research interview. Medical Education, 40(4), 314-318.

Crabtree, B. F., \& Miller, W. L. (1999). Doing qualitative research. SAGE Publications. Retrieved from http://books.google.com/books?hl=en\&lr=\&id=MEd2AwAAQBAJ\&pgis=1.

Creswell, J. W. (2012). Educational research: planning, conducting, and evaluating quantitative and qualitative research. Educational Research (Vol. 4, Fourth ed.). London: Pearson. https://doi.org/10.1017 /CBO9781107415324.004.

De Vita, G., \& Case, P. (2003). Rethinking the internationalisation agenda in UK higher education. Journal of Further and Higher Education, 27(4), 383-398. https://doi.org/10.1080/0309877032000128082.

Groenewald, T. (2004). A phenomenological research design illustrated. International Journal of Qualitative Methods, 3(1), 42-55. Retrieved from https://doi.org/10.1177/160940690400300104.

Hardy, C., \& Tolhurst, D. (2014). Epistemological beliefs and cultural diversity matters in management education and learning: a critical review and future directions. Academy of Management Learning \& Education, 13(2), 265-289.

Hislop, D. (2013). Knowledge management in organizations: a critical introduction. Oxford: Oxford University Press.

Howells, J. (1996). Tacit knowledge. Technology Analysis \& Strategic Management, 8(2), 91-106.

Jabbar, A., \& Hardaker, G. (2013). The role of culturally responsive teaching for supporting ethnic diversity in British University Business Schools. Teaching in Higher Education, 1-13. https://doi.org/10.1080/13562517.2012.725221.

Jobber, D., \& Ellis-Chadwick, F. (2012). Principles and practice of marketing. London: McGraw-Hill Higher Education.

Kehm, B. K. (2014). How Germany managed to abolish university tuition fees. Retrieved from http://theconversation.com/how-germany-managed-to-abolish-university-tuition-fees-32529..

King, N. (2004). Using templates in the thematic analysis of texts. In C. Cassell \& G. Symon (Eds.), Essential guide to qualitative methods in organizational research (pp. 256-270). London: Sage Publications.

King, N. (2012). Doing template analysis. In G. Symon \& C. Cassell (Ed.), Qualitative Organizational Research: Core Methods and Current Challenges, (pp. 426-450). London: Sage

King, N., \& Horrocks, C. (2010). Interviews in qualitative research. London: SAGE Publications Limited.

Kinman, G. (2001). Pressure points: a review of research on stressors and strains in UK academics. Educational Psychology, 21(4), 473-492. https://doi.org/10.1080/01443410120090849.

Kinman, G., \& Jones, F. (2003). "Running up the down escalator": stressors and strains in UK academics. Quality in Higher Education, 9(1), 21-38. https://doi.org/10.1080/13538320308162.

Langdridge, D. (2007). Phenomenological psychology: theory, research and method. Harlow: Pearson Education.

Lomas, L. (2007). Are students customers? Perceptions of academic staff. Quality in Higher Education, 13(1), 31-44. https://doi.org/10.1080/13538320701272714.

Long, G. L., \& Lake, E. S. (1996). A precondition for ethical teaching: Clarity about role and inequality. Teaching Sociology, 24(1), 111-113.

Lumby, J., \& Foskett, N. (2015). Internationalization and culture in higher education. Educational Management Administration \& Leadership, 44(1), 95-111. https://doi.org/10.1177/1741143214549978.

Lynch, K. (2006). Neo-liberalism and marketisation: the implications for higher education. European Educational Research Journal, 5(1), 1-17. https://oi.org/10.2304/eerj.2006.5.1.1.

Marginson, S. (2012). The impossibility of capitalist markets in higher education. Journal of Education Policy, 28(3), 353-370. https://doi.org/10.1080/02680939.2012.747109.

Marginson, S., \& Considine, M. (2002). The enterprise university: power, governance and reinvention in Australia. Cambridge: Cambridge university press.

Margolis, J. D., \& Molinsky, A. (2008). Navigating the bind of necessary evils: psychological engagement and the production of interpersonally sensitive behavior. Academy of Management Journal, 51(5), 847-872.

Meek, V. L. (2000). Diversity and marketisation of higher education: incompatible concepts? Higher Education Policy, 13(1), 23-39.

Miles, M. B., \& Huberman, A. M. (1994). Qualitative data analysis: an expanded sourcebook. Thousand Oaks: Sage.

Molesworth, M., Nixon, E., \& Scullion, R. (2009). Having, being and higher education: the marketisation of the university and the transformation of the student into consumer. Teaching in Higher Education, 14(3), 277287. https://doi.org/10.1080/13562510902898841.

Naidoo, R., \& Jamieson, I. (2005). Empowering participants or corroding learning? Towards a research agenda on the impact of student consumerism in higher education. Journal of Education Policy, 20(3), 267-281.

Naidoo, R., \& Williams, J. (2015). The neoliberal regime in English higher education: charters, consumers and the erosion of the public good. Critical Studies in Education, 56(2), 208-223. https://doi.org/10.1080 /17508487.2014.939098.

Naidoo, R., Shankar, A., \& Veer, E. (2011). The consumerist turn in higher education: policy aspirations and outcomes. Journal of Marketing Management, 27(11-12), 1142-1162. https://doi.org/10.1080/0267257 X.2011.609135. 
Natale, S. M., \& Doran, C. (2012). Marketization of education: an ethical dilemma. Journal of Business Ethics, 105(2), 187-196. https://doi.org/10.1007/s10551-011-0958-y.

Nixon, E., Scullion, R., \& Hearn, R. (2016). Her majesty the student: marketised higher education and the narcissistic (dis)satisfactions of the student-consumer. Studies in Higher Education, 1-21. https:/doi. org/10.1080/03075079.2016.1196353.

Nonaka, I., \& Konno, N. (1998). The concept of " ba": building a foundation for knowledge creation. California Management Review, 40(3), 40-54.

Nonaka, I., \& Takeuchi, H. (1995). The knowledge-creating company: how Japanese companies create the dynamics of innovation. Oxford: Oxford university press.

Olssen, M., \& Peters, M. A. (2005). Neoliberalism, higher education and the knowledge economy: from the free market to knowledge capitalism. Journal of Education Policy, 20(3), 313-345. https://doi.org/10.1080 /02680930500108718.

Pathirage, C. P., Amaratunga, D. G., \& Haigh, R. P. (2007). Tacit knowledge and organisational performance: construction industry perspective. Journal of Knowledge Management, 11(1), 115-126.

Polanyi, M. (1966). The tacit dimension. London: Routledge and Kegan Paul.

Potts, M. (2005). The consumerist subversion of education. Academic Questions, 18(3), 54-64. https://doi. org/10.1007/s12129-005-1018-9.

Ritchie, J., Lewis, J., \& Elam, G. (2003). Designing and selecting samples. In J. Ritchie \& J. Lewis (Eds.), Qualitative research practice: a guide for social science students and researchers (pp. 77-108). London: Sage.

Ritzer, G. (1996). McUniversity in the postmodern consumer society. Quality in Higher Education, 2(3), 185-199.

Ryle, G. (1949). The concept of mind. Chicago: University of Chicago Press.

Schapper, J. M., \& Mayson, S. E. (2004). Internationalisation of curricula: an alternative to the Taylorisation of academic work. Journal of Higher Education Policy and Management, 26(2), 189-205. https://oi. org/10.1080/1360080042000218258.

Turner, Y. (2006). Chinese students in a UK business school: hearing the student voice in reflective teaching and learning practice. Higher Education Quarterly, 60(1), 27-51. https://doi.org/10.1111/j.14682273.2006.00306.x.

Tytherleigh, M. Y., Webb, C., Cooper, C. L., Ricketts, C., Tytherleigh, M. Y., Webb, C., et al. (2005). Occupational stress in UK higher education institutions: a comparative study of all staff categories. Higher Education Research \& Development, 24, 41-61. https://doi.org/10.1080/0729436052000318569.

Warwick, P. (2014). The international business of higher education-a managerial perspective on the internationalisation of UK universities. The International Journal of Management Education, 12(2), 91103. https://doi.org/10.1016/j.ijme.2014.02.003.

Woodall, T., Hiller, A., \& Resnick, S. (2014). Making sense of higher education: students as consumers and the value of the university experience. Studies in Higher Education, 39(1), 48-67. https://doi.org/10.1080 /03075079.2011.648373. 